\title{
Gibbons sees Gore links as asset for science
}

Washington. The new director of the White House Office of Science and Technology Policy (OSTP) hopes that Vice President Al Gore's interest in the subject will give science a greater voice in shaping the policies of the Clinton administration. And he suggested that President Bill Clinton may take a different approach on such megaprojects as the Superconducting Super Collider (SSC) and Space Station Freedom.

John Gibbons was last week sworn in as director of OSTP after the Senate confirmed him unanimously (his appointment on Christmas Eve as the president's science adviser took effect immediately). Earlier in the week, during his confirmation hearing before the Senate Committee on Commerce, Science and Transportation, Gibbons gave hints of the new president's thinking on a number of important issues facing the scientific community.

The creation of a civilian agency modelled on the successful Defense Advance Research Projects Agency in the Pentagon, at one point a major plank in Clinton's campaign platform to strengthen US high-technology industries, no longer appears to be under consideration. Instead, Gibbons said in response to questioning, "the most opportune way is to fully utilize what we do now". That means yet another review of the multi-billion-dollar national laboratories, many created to fight the Cold War and now looking for civilian missions, increased support for joint projects with industry and a much larger budget for the National Institutes of Standards and Technology, home to the fledgling Technology Administration.

Yet even such an innocuous approach as greater collaboration faces potential hazards. Are there any restrictions that the administration should place on companies to prevent them from taking their knowledge overseas and using foreign labour to make the advanced products, wondered Senator John Kerry (Democrat, Massachusetts). Gibbons parried the question by saying that the Clinton administration would look at the reasons behind such US corporate flight, as well as why many young high-technology US companies must look for help overseas rather than within the United States. "I think that the jobs will stay here if our people are productive and well-trained", he said.

But Clinton is also eager to reexamine current policies in important areas, Gibbons asserted. In particular, Gibbons suggested that the \$8.5-billion SSC and \$30-billion space station would receive much closer scrutiny as the president looks for ways to reduce the $\$ 300$-billion federal deficit. The failure to obtain significant contributions to the SSC from other countries (see Nature 361, 288; 1993) can no longer be ignored, he said. Similarly, he added, the space station includes certain technologies "that should be international from the outset". Both projects are expected to come under attack this year from Congress, and their future will be precarious if the new president is less supportive of them than George Bush.

D. Allan Bromley, Gibbons' predecessor, put great stock in a series of interagency committees that reviewed US efforts in sev-

\section{IMAGE UNAVAILABLE FOR COPYRIGHT REASONS}

John Gibbons, left, talks with Sen. John Warner before his confirmation hearing last week.

eral scientific fields. Gibbons believes that such panels, called Federal Coordinating Committees for Science, Engineering and Technology (FCCSET), "have been effective in some instances" but that more can be done with them. He said he hoped to benefit from a close relationship with Gore because "the science adviser's ability to convene a group [such as FCCSET] is much less than the vice president's". He also said that he

expects to put greater emphasis on environmental issues and that one of his four deputies will be given that portfolio among other duties.

Although it has been more than a dozen years since Gibbons worked at a university (he directed a centre on energy and the environment at the University of Tennessee before becoming director of the congressional Office of Technology Assessment in 1979), he sprang to their defence in response to questions about federal investigations of conflict of interest, misuse of research dollars and scientific misconduct. Gibbons said that univer-

sities should be treated differently from industry because "we have to remember that they aren't out there making money - in fact, they often lose it.... I hope that we remember they are our partners, not our adversaries, in achieving national goals".

What a science adviser thinks matters little, of course, unless he has the ear of his bosses in the White House. Thanks to his status as a member of the newly created National Economic Council, Gibbons spent last weekend with Clinton and his cabinet at the presidential retreat of Camp David, 90 miles from Washington, mapping out an economic strategy. Although his presence is seen as a positive sign that Clinton intends to incorporate science into his deliberations, a more significant measure will come in mid-March when the president submits his first budget.

Jeffrey Mervis

\section{Grace period urged for patents}

London. Pressure is growing on the British government to give research scientists a one-year 'grace period' after the publication of research findings in which to apply for a patent on their results. The change from the present policy of having to apply before publication would bring UK policies in line with those in the United States.

The latest support for this proposal, which has already been recommended by the Science and Engineering Research Council, comes from the government's top science advisory committee, which also suggests that all biomedical research students be given training in the importance and evaluation of intellectual property rights. Both recommendations are made in a report* published this week.

The recommendations are intended to help address what a committee chaired by Peter Doyle, director of research and technology for ICI plc, describes as a "development gap" between research laboratories and industrial exploitation - a gap which, the committee says, is a "particular difficulty" in Britain. One suggested remedy is the creation of a new programme, MEDILINK, by the Department of Trade and Industry, to increase "towards market" research and development through projects linking academic and industrial researchers.

The current system for managing intellectual property in British universities is "underdeveloped and under-resourced", according to scientists contacted by the committee, and pressure to publish research quickly "has restricted the interaction between academia and industry." To avoid this - and presumably to give industry a chance to identify patentable discoveries in the scientific literature - it suggests legislation allowing both the British and the European Patent Offices to grant a one-year grace period.

David Dickson

* A Report on Medical Research and Health. Advisory Council on Science and Technology. Office of Science and Technology. HMSO. $£ 13.00$ 